\title{
Substituting corn silage with reconstituted forage or nonforage fiber sources in the starter feed diets of Holstein calves: Effects on intake, meal pattern, sorting, and health
}

\section{S. Kargar* and M. Kanani}

Department of Animal Science, School of Agriculture, Shiraz University, Shiraz 71441-65186, Iran

\section{ABSTRACT}

We examined the effect of replacing corn silage (CS) with reconstituted alfalfa hay (RAH) or reconstituted beet pulp (RBP) in the starter diets on feeding behavior, sorting, and health criteria using 54 neonatal female Holstein calves that were assigned randomly to 3 groups receiving starter diets containing CS (10\% on a dry matter basis), RAH, or RBP. The starter diets had the same nutrient composition and moisture level but differed in particle size distribution. Calves fed CS tended to have a lower intermeal interval compared with calves fed RAH before weaning; however, meal frequency and duration, eating rate, and meal size were not affected by treatment before and after weaning, which resulted in no changes in feed intake and time spent eating. Rumination frequency was higher for calves fed CS than for calves fed RAH or RBP after weaning. Feeding RBP decreased rumination duration compared with CS and RAH after weaning; however, calves fed RBP had a higher rumination bout interval compared with calves fed CS. Calves fed CS spent more time ruminating compared with calves fed RAH or RBP after weaning. Feeding CS tended to decrease and decreased time devoted to standing and lying, respectively, compared with calves fed RBP; however, calves fed RBP tended to spend more time on nonnutritive oral behaviors compared with calves fed RAH. Calves fed CS sorted against particles retained on the 8-mm sieve of the Penn State Particle Separator (PSPS) and for particles retained on the 1.18-mm sieve of the PSPS. Feeding RAH increased sorting for particles retained on the 8- and 1.18-mm sieves of the PSPS. Calves fed RBP sorted only for particles retained on the $1.18-\mathrm{mm}$ sieve of the PSPS. Calves fed RBP tended to be more susceptible to developing pneumonia compared with calves fed CS or RAH; however, frequency and duration of

Received February 8, 2019.

Accepted April 5, 2019.

*Corresponding author: skargar@shirazu.ac.ir diarrhea and pneumonia or number of days needed to medicate the diseases were unchanged across treatment groups. Initial (d 3) blood total protein concentration was similar $(6.51 \mathrm{~g} / \mathrm{dL})$ across treatment groups. Overall, replacing CS with RAH or RBP did not affect time devoted to eating and feed intake due to no significant changes in meal size or intermeal interval before and after weaning. Calves showed feed sorting at the extent to which they balanced intake of nutrients and met their nutritional needs. Calves in general were healthy; therefore, CS, RAH, or RBP can be used interchangeably based on availability and competitive feed price. Key words: beet pulp, calf nutrition, diarrhea and pneumonia, feeding behavior, reconstitution

\section{INTRODUCTION}

It has been shown that providing a TMR for dairy calves (2 to 5 mo old) would offer a better balance of nutrient intake by preventing individual sorting for forage or concentrate (Borland and Kesler, 1979). Feeding a TMR to replacement dairy heifers (5 mo old) increased the distribution of DMI over the course of the day, increased time devoted to eating by decreasing feeding rate, reduced sorting, and led to a more balanced intake of nutrients across the day and to increased fecal consistency (Greter et al., 2010). However, dairy calves actively sort TMR against longer particles and for shorter particles (Miller-Cushon et al., 2013; Kargar and Kanani, 2019), a pattern of feed sorting similar to that observed in dairy heifers and cows (Leonardi and Armentano, 2003; Greter et al., 2010; Kargar et al., $2013,2014)$. Feed sorting may be affected by several factors, including feeding frequency (DeVries et al., 2005), amount of feed provision (Greter and DeVries, 2011), dietary moisture level (Leonardi et al., 2005; Beiranvand et al., 2019; Kargar and Kanani, 2019), forage level and particle size (Leonardi and Armentano, 2003), and forage source (Castells et al., 2012). When corn silage (CS) and alfalfa hay $(\mathbf{A H})$ were offered to young calves separately from the starter feed, Castells 
et al. (2012) showed that calves fed CS had increased intake of concentrate compared with forage, indicating that the source of forage provided affects feed sorting. Little is known on how the forage (e.g., $\mathrm{CS}$ or $\mathrm{AH}$ ) or nonforage (e.g., beet pulp; BP) fiber sources used in TMR fed to dairy calves can affect sorting behavior. Therefore, examination of feed sorting when calves consume starter diets containing CS and reconstituted AH (RAH) or reconstituted BP (RBP; by soaking in tap water for $24 \mathrm{~h}$ to achieve a theoretical DM content of $20 \%$ ) is required.

In recent years, many attempts have been made to increase DMI in dairy calves fed as TMR by moisturizing starter feeds (Beiranvand et al., 2016, 2019; Kargar and Kanani, 2019) and feeding more digestible source of nonforage fiber or silage-based starter diets. Adding water to the concentrate portion $(90 \%$ of dietary DM) of starter diet and decreasing DM content of dry TMR from 90 to $50 \%$ improved ADG in dairy calves by increasing DMI and VFA (especially acetate and propionate) proportions (Beiranvand et al., 2016, 2019). Providing a starter diet containing $10 \%$ dry AH versus RAH and decreasing DM content of dry TMR from 91.2 to $83.8 \%$ increased DMI $(+24 \%$; by increasing NDF digestibility) and ADG $(+9 \%)$ in dairy calves before weaning (Kargar and Kanani, 2019). Maktabi et al. (2016) observed higher DMI, ADG, and BW for dairy calves when a starter diet was supplemented with $10 \%$ (vs. 0\%) dry sugar BP. There is growing interest in feeding silage-based TMR to dairy calves from early in life, which is a practical feeding strategy for dairy farmers in addition to providing a more balanced and palatable source of nutrients for growing young calves (Mirzaei et al., 2016, 2017). Supplementing starter diets with $15 \%$ CS (vs. $0 \%$ ) or $15 \%$ CS versus dry $\mathrm{AH}$ increased DMI, ADG, and BW in dairy calves, possibly due to reduced dustiness or higher palatability of the starter feed with increased dietary moisture (Mirzaei et al., 2016, 2017). However, it is unclear how calves benefit from CS compared with RAH or RBP when dietary moisture level is similar across diets.

There is paucity of data to reveal how changes in the forage ( $\mathrm{CS}$ or $\mathrm{AH}$ ) or nonforage (BP) fiber sources of the starter diets affect the feed intake and sorting activity of dairy calves when fed at the level $(\leq 10 \%$ of dietary DM) to avoid gut fill effect (Imani et al., 2017). Furthermore, limited data are available on the effects of forage or nonforage fiber sources on prevention and medication of diseases (e.g., diarrhea and pneumonia) in dairy calves before weaning. The main purpose of this trial was to investigate the potential benefits of replacing CS with RAH or RBP in a finely ground starter diet containing similar nonforage or forage levels $(10 \%$ of dietary DM) and NDF contents. We hypothesized that DMI and sorting activity in dairy calves fed RAH or RBP would be comparable with those of dairy calves fed CS within targeted levels of NDF (16-18\%) in starter diets, which is important for maintaining feed intake and well-being (Beiranvand et al., 2016, 2019). To this end, we measured the nutrient intake, meal pattern, sorting behavior, health variables, and blood total protein concentration in Holstein calves.

\section{MATERIALS AND METHODS}

\section{Calves, Treatments, and Management}

All animal procedures were approved by the Animal Care Committee of Shiraz University based on guidelines from the Iranian Council of Animal Care (1995). Fifty-four neonatal female Holstein calves (3 d of age; $39.8 \pm 1.36 \mathrm{~kg}$ of $\mathrm{BW}$; mean $\pm \mathrm{SE}$ ) were housed in a naturally ventilated barn with pens $(2.9 \mathrm{~m}$ length $\times 1.1$ $\mathrm{m}$ width $\times 1.8 \mathrm{~m}$ height) bedded with wood shavings (minimum theoretical length cut of $50 \mathrm{~mm}$ ). Bedding was refreshed every day and manure was removed daily to keep the pens visibly clean and dry. Calves were fed a total of $5.5 \mathrm{~L}$ of colostrum, with $3.5 \mathrm{~L}$ fed within 2 $\mathrm{h}$ of life and $2 \mathrm{~L}$ fed $8 \mathrm{~h}$ after the first feeding. Calves consumed transition milk (4 L; on d 2 of life) or waste milk (from d 3 onward) 2 times daily (at 0900 and 1700 h) at equal amounts. Milk was fed by bucket at $6 \mathrm{~L} / \mathrm{d}$ from d 3 to $43,4 \mathrm{~L} / \mathrm{d}$ from d 44 to 46 , and $2 \mathrm{~L} / \mathrm{d}$ from d 47 to 49 of age. Calves were weaned on d 50 and remained in the trial until d 70 .

Calves were allocated randomly to 1 of the 3 dietary treatments ( $\mathrm{n}=18 /$ treatment): (1) a diet containing $10 \%$ (on a DM basis) CS, (2) a diet containing $10 \%$ $\mathrm{RAH}$, and (3) a diet containing 10\% RBP (Table 1). Alfalfa hay was chopped with a theoretical length cut of $30 \mathrm{~mm}$ using a harvesting machine with a screen size regulator (Golchin Trasher Hay Co., Isfahan, Iran). The particle size of $\mathrm{AH}(3-5 \mathrm{~mm}$ as mean geometric) and CS (12-15 $\mathrm{mm}$ as mean geometric) was in the range used in the majority of dairy farms in Iran (Kargar et al., 2013, 2014; Table 2). Alfalfa hay and BP were reconstituted using tap water $24 \mathrm{~h}$ before feeding by placing the required amounts of dry $\mathrm{AH}$ or $\mathrm{BP}$ into an industrial container (Iran Plast Co., Isfahan, Iran; kept at ambient temperature under shade) and mixing thoroughly (every $6 \mathrm{~h}$ ) to achieve a theoretical DM content of $20 \%$. Corn and barley grains were ground using a hammer mill with 2-mm screen size (model 5543 GEN, Isfahan Dasht, Isfahan, Iran). Calves had unlimited access to fresh, clean drinking water and TMR formulated according to NRC (2001). 
Table 1. Ingredients and chemical composition (\% of DM unless otherwise noted) of the experimental diets

\begin{tabular}{|c|c|c|c|}
\hline \multirow[b]{2}{*}{ Item } & \multicolumn{3}{|c|}{ Diet $^{1}$} \\
\hline & CS & $\mathrm{RAH}$ & $\mathrm{RBP}$ \\
\hline \multicolumn{4}{|l|}{ Ingredient } \\
\hline Ground corn grain & 54.0 & 54.0 & 54.0 \\
\hline Ground barley grain & 10.1 & 10.1 & 10.1 \\
\hline Soybean meal & 23.0 & 23.0 & 23.0 \\
\hline Corn silage & 10.0 & - & - \\
\hline Reconstituted alfalfa hay & - & 10.0 & - \\
\hline Reconstituted sugar beet pulp & - & - & 10.0 \\
\hline Vitamin and mineral mixture 2 & 1.0 & 1.0 & 1.0 \\
\hline Calcium carbonate & 1.3 & 1.3 & 1.3 \\
\hline Salt & 0.6 & 0.6 & 0.6 \\
\hline \multicolumn{4}{|l|}{ Chemical composition } \\
\hline DM & 84.7 & 84.1 & 84.4 \\
\hline $\mathrm{CP}$ & 19.9 & 20.3 & 20.0 \\
\hline $\mathrm{NFC}^{3}$ & 52.7 & 53.8 & 54.6 \\
\hline $\mathrm{NDF}$ & 17.6 & 16.7 & 16.1 \\
\hline Ether extract & 3.6 & 3.3 & 3.2 \\
\hline Ash & 6.2 & 6.0 & 6.1 \\
\hline Calcium $^{4}$ & 0.69 & 0.73 & 0.70 \\
\hline Phosphorus ${ }^{4}$ & 0.38 & 0.38 & 0.36 \\
\hline $\mathrm{ME}{ }^{4} \mathrm{Mcal} / \mathrm{kg}$ of DM & 3.08 & 3.06 & 3.11 \\
\hline $\mathrm{NE}_{\mathrm{M}},{ }^{4}$ Mcal/kg of DM & 2.31 & 2.30 & 2.33 \\
\hline $\mathrm{NE}_{\mathrm{G}},{ }^{4} \mathrm{Mcal} / \mathrm{kg}$ of DM & 1.75 & 1.75 & 1.77 \\
\hline
\end{tabular}

${ }^{1} \mathrm{CS}=$ starter diet containing $10 \%$ corn silage RAH $=$ starter diet containing $10 \%$ reconstituted alfalfa hay; $\mathrm{RBP}=$ starter diet containing $10 \%$ reconstituted beet pulp.

${ }^{2}$ Contained per kilogram of supplement: 975,000 IU of vitamin A, $750,000 \mathrm{IU}$ of vitamin D, 1,800 IU of vitamin E, $143 \mathrm{~g}$ of Zn, $76 \mathrm{~g}$ of $\mathrm{Mn}, 48.6 \mathrm{~g}$ of $\mathrm{Cu}, 19.5 \mathrm{~g}$ of Se, $18.4 \mathrm{~g}$ of $\mathrm{Fe}, 8 \mathrm{~g}$ of $\mathrm{Ca}$, and $1.3 \mathrm{~g}$ of $\mathrm{Co}$. ${ }^{3} \mathrm{NFC}=100-(\mathrm{CP}+\mathrm{NDF}+$ ether extract + ash $)(\mathrm{NRC}, 2001)$. ${ }^{4}$ Calculated from NRC (2001).

\section{Feed Sampling and Analyses}

Samples of $\mathrm{CS}$ and $\mathrm{AH}(\mathrm{n}=7$; pooled by forage every $10 \mathrm{~d}$ over the trial period), treatment TMR $(\mathrm{n}=$ 7; pooled by treatment every $10 \mathrm{~d}$ over the trial period), and individual refusals $(\mathrm{n}=4$; pooled by calf every $10 \mathrm{~d}$ starting on d 31 until the end of the trial period) were taken for particle size separation. A Penn State Particle Separator (PSPS; The Pennsylvania State University, University Park; Nasco, Fort Atkinson, WI) equipped with 3 sieves $(19,8$, and $1.18 \mathrm{~mm}$ ) and a bottom pan was used to separate samples for particle size distributions into long $(>19 \mathrm{~mm})$, medium $(\geq 8$ and $<19 \mathrm{~mm})$, short $(\geq 1.18$ and $<8 \mathrm{~mm})$, and fine $(<1.18 \mathrm{~mm})$ fractions (Kononoff et al., 2003). After separation with the PSPS, the DM concentration of each separated fraction was determined by drying at $100^{\circ} \mathrm{C}$ in a forced-air oven for $24 \mathrm{~h}$ (AOAC International, 2002; method 925.40). The physical effectiveness factor (pef) was calculated as the DM proportion of particles retained on 3 sieves (pef $_{>1.18}$; Kononoff et al., 2003) of the PSPS. The physically effective NDF of 3 sieves $\left(\mathbf{p e N D F} \mathbf{F}_{>1.18}\right)$ was calculated by multiplying the NDF concentration of the feed by the fraction on pef $>1.18$. Geometric mean particle size of the forages and starter diets was calculated according to ASAE (1995; method S424.1).

\section{Feed Preference and Chewing Behavior}

The sorting index was computed as the actual intake of each fraction of the PSPS expressed as a percentage of the predicted intake of that fraction (Leonardi

Table 2. Physical characteristics of forage, nonforage, and experimental diets measured using the Penn State Particle Separator ${ }^{1}$

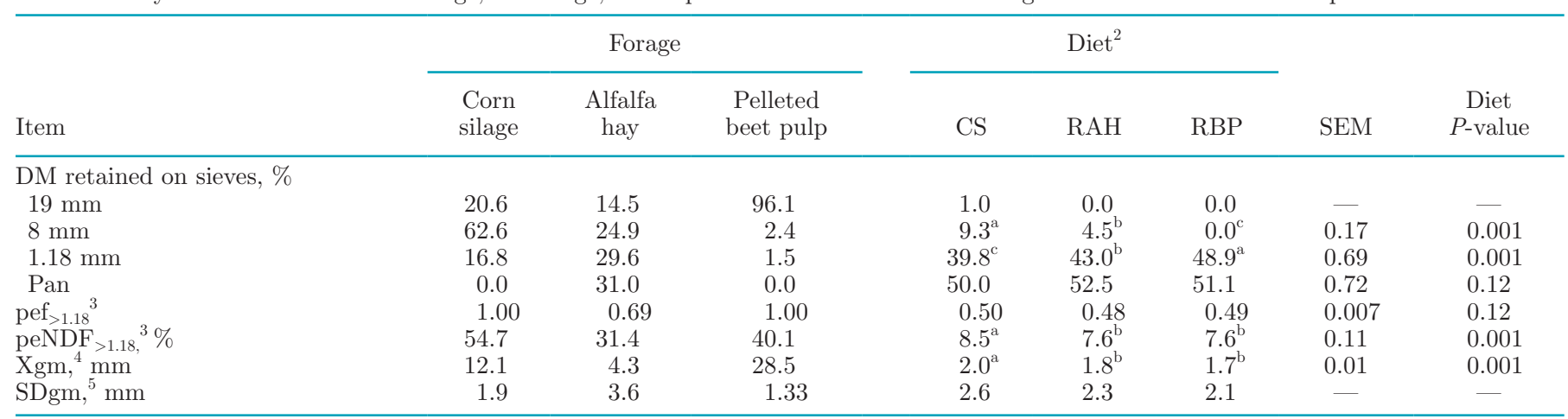

\footnotetext{
${ }^{\mathrm{a}-\mathrm{c}}$ Means within a row with different superscripts are significantly different $(P \leq 0.05)$.
}

${ }^{1}$ Particle length variables were measured using the Penn State Particle Separator (The Pennsylvania State University, University Park; Kononoff et al., 2003).

${ }^{2} \mathrm{CS}=$ starter diet containing $10 \%$ corn silage; $\mathrm{RAH}=$ starter diet containing $10 \%$ reconstituted alfalfa hay; RBP $=$ starter diet containing $10 \%$ reconstituted beet pulp.

${ }^{3}$ pef $_{>1.18}=$ physical effectiveness factor determined as the proportion of particles retained on 3 sieves $($ Kononoff et al., 2003); peNDF $>1.18=$ physically effective NDF determined as NDF content of TMR multiplied by pef $>1.18$.

${ }^{4}$ Geometric mean particle size, calculated according to ASAE (1995) method S424.1.

${ }^{5}$ Geometric SD of particle size, calculated according to ASAE (1995) method S424.1. 
and Armentano, 2003). Predicted intake of a fraction was computed as the product of the DMI of the total diet multiplied by the DM percentage of the fraction in the fed TMR. Values equal to $100 \%$ indicated no sorting, values $<100 \%$ indicated selective refusals (sorting against), and values $>100 \%$ indicated preferential consumption (sorting for) for a particular fraction. To test whether calves were sorting the diet for each fraction (depending on the time period), 1 sorting value was generated per calf per $10 \mathrm{~d}$ starting on d 31 until the end of the trial period.

Behavioral data were monitored by visual observations of all calves every 5 min for eating, ruminating, resting, standing, lying, drinking, and nonnutritive oral behaviors (NNOB; when the animal licked any surface, tongue rolling, or wood-shavings consumption) over a 12-h period (between 0900 and $2100 \mathrm{~h}$ ) once per 3 consecutive $d$ before weaning ( $d$ 37-39 of the trial) as well as once per 3 consecutive days after weaning (d 67-69 of the trial; Kargar and Kanani, 2019). A period of eating was defined as at least 1 observation of eating activity occurring after at least 5 min without eating. Meal frequency was defined as the number of bouts during a 12-h period. The meal duration ( $\mathrm{min} / \mathrm{meal})$ was computed as the time from the beginning of the first feeding event until an interval between events and averaged for each calf. Intervals ( $\mathrm{min}$ ) between feeding events were computed from the end of a feeding event to the beginning of the next and averaged for each calf. The meal size (grams of starter DMI during a 12-h period/number of meals during that period) was the total amount of starter DM ingested during each meal. The same procedure was used to calculate the rumination pattern.

\section{Health and Blood Total Protein Concentration}

Calf health checks were performed daily by a veterinarian, blinded to the treatments, during the preweaning period (d 1-49). Rectal temperature was measured daily between 1300 and $1400 \mathrm{~h}$ using a digital thermometer (model FT 15/1; Beurer GmbH, Ulm, Germany) placed in the rectum for $1 \mathrm{~min}$. Fecal scores were assigned on a 1 -to- 5 scale: $1=$ normal; $2=$ soft to loose; $3=$ loose to watery; $4=$ watery, mucous, and slightly bloody; and $5=$ watery, mucous, and bloody (Heinrichs et al., 2003). General appearance scores were assigned on a 1 -to- 5 scale: $1=$ normal and alert; $2=$ ears drooped; $3=$ head and ears drooped, dull eyes, slightly lethargic; $4=$ head and ears drooped, dull eyes, lethargic; and $5=$ severely lethargic (Heinrichs et al., 2003). Rectal temperature was categorized as number of days with temperature $\geq 40^{\circ} \mathrm{C}$, fecal score was categorized as number of days with fecal score $\geq 3$, and general appearance was categorized as number of days with general appearance score $\geq 2$. These categories were denoted as days with abnormal rectal temperature, fecal score, and general appearance, respectively, and calves were examined by the veterinarian to confirm diarrhea and pneumonia diagnoses. The treatment of diseases (diarrhea and pneumonia) followed the standard operating procedures at the Foudeh-Sepahan Agri. Animal Production Co. (Isfahan, Iran), and sick calves were treated by the veterinarian accordingly. In the case of nonresponse to the applied procedures, the veterinarian did not continue treatment with additional protocol.

Blood samples were collected $4 \mathrm{~h}$ after morning feeding into vacuum serum separator tubes containing clot activator on the starting day of study $(72 \mathrm{~h}$ after birth) to evaluate passive transfer status by measuring total protein. Samples were centrifuged immediately at $3,000 \times g$ for $20 \mathrm{~min}$ at $4^{\circ} \mathrm{C}$, and $1.5 \mathrm{~mL}$ of serum was transferred into 2 -mL microtubes and kept immediately at $-20^{\circ} \mathrm{C}$ for the next analyses. Blood total protein concentration was spectrophotometrically (Unicco, 2100, Zistchemi, Tehran, Iran) determined using a commercially available kit (Pars Azmoon Co., Tehran, Iran; cat. no. 1-500-028) according to the manufacturer's instructions.

\section{Statistical Analyses}

Data on nutrient intake (d 1-49, d 50-70, and d 31-70) and sorting behavior (d 31-70) were analyzed using the MIXED procedure of SAS (version 9.4, SAS Institute Inc., Cary, NC) with time (1- or 10-d periods) as repeated measures. The effects of diet, time, and diet $\times$ time interaction were considered as fixed and calf as a random effect. Various covariance structures [including CS, Simple, UN, TOEP, AR (1), ARH (1), and ANTE (1)] were examined to find the best-fitted structure for the model. First-order autoregressive covariance structure was the best fit for these data as determined by the lowest Akaike information criterion. Data on blood total protein and feeding and chewing activity were analyzed using the same above-mentioned model without the time effect. To determine whether sorting occurred, sorting activity for each fraction was tested for a difference from $100 \%$ using the $t$-test procedure of SAS. Also, data for particle size distribution, pef, peNDF of treatment TMR, and geometric mean particle size were analyzed by including diet as a fixed effect and period as a random effect. Least squares means for time and diet $\times$ time effects were separated using a Tukey adjustment when the overall $F$-test was $P \leq 0.05$. Trends were declared when $0.05<P \leq 0.10$.

Models for occurrence of diarrhea $\geq 3$, pneumonia, need for treatment, rectal temperature $\geq 40^{\circ} \mathrm{C}$, and 
Table 3. Nutrient intake as influenced by feeding diets containing $10 \%$ corn silage (CS) and reconstituted alfalfa hay (RAH) or reconstituted beet pulp (RBP) to Holstein calves

\begin{tabular}{|c|c|c|c|c|c|c|c|}
\hline \multirow[b]{2}{*}{ Item } & \multicolumn{3}{|c|}{ Diet } & \multirow[b]{2}{*}{ SEM } & \multicolumn{3}{|c|}{$P$-value } \\
\hline & CS & $\mathrm{RAH}$ & $\mathrm{RBP}$ & & Diet & Time & $\begin{array}{c}\text { Diet } \\
\times \text { time }\end{array}$ \\
\hline \multicolumn{8}{|l|}{ Starter feed DMI, g/d } \\
\hline Preweaning (d 1-49) & 300 & 389 & 461 & 73.6 & 0.30 & 0.001 & 0.14 \\
\hline Postweaning (d 50-70) & 2,073 & 2,096 & 2,397 & 171.3 & 0.32 & 0.001 & 0.19 \\
\hline d $31-70$ & 1,353 & 1,397 & 1,622 & 127.9 & 0.27 & 0.001 & 0.13 \\
\hline \multicolumn{8}{|c|}{ Starter feed CP intake, $\mathrm{g} / \mathrm{d}$} \\
\hline Postweaning (d 50-70) & 402 & 413 & 465 & 33.3 & 0.35 & 0.001 & 0.11 \\
\hline d $31-70$ & 263 & 275 & 315 & 24.8 & 0.29 & 0.001 & 0.30 \\
\hline \multicolumn{8}{|c|}{ Starter feed NDF intake, $\mathrm{g} / \mathrm{d}$} \\
\hline Preweaning (d 1-49) & 51 & 62 & 72 & 11.9 & 0.46 & 0.001 & 0.12 \\
\hline Postweaning (d 50-70) & 350 & 335 & 372 & 27.6 & 0.64 & 0.001 & 0.14 \\
\hline d $31-70$ & 229 & 224 & 251 & 20.5 & 0.57 & 0.001 & 0.25 \\
\hline
\end{tabular}

general appearance $\geq 2$ were examined by logistic regression using a binomial distribution in the GLIMMIX procedure in SAS. Odds ratio was used to compare the likelihood for calves on each experimental diet to experience any event. Frequency and duration of diarrhea, pneumonia, administration of medication, and number of days with diarrhea $\geq 3$, pneumonia, rectal temperature $\geq 40^{\circ} \mathrm{C}$, and general appearance $\geq 2$ were examined with a Poisson distribution using the GENMOD procedure of SAS.

\section{RESULTS}

\section{Diet Characteristics and Particle Size Distribution}

The percentage of particles retained on the top sieve $(>19 \mathrm{~mm}$ ) of the PSPS was negligible in CS (only 1\%) but was zero in RAH and RBP (Table 2). The percentage of particles retained on the 8-mm sieve of the PSPS was zero in RBP but was greater in CS compared with RAH $(P=0.001)$. The percentage of particles retained on the $1.18-\mathrm{mm}$ sieve of the PSPS was greater in RBP compared with other diets and was greater in RAH relative to $\mathrm{CS}(P=0.001)$. The feed materials retained on the bottom pan (51.2\% on average) were not affected by diet $(P=0.12)$. Feeding CS increased peNDF $>1.18(P$ $=0.001$; but not pef $\left._{>1.18}\right)$ and geometric mean particle size $(P=0.001)$ compared with RAH and RBP.

\section{Intake and Sorting Activity}

Replacing CS with RAH or RBP did not affect nutrient intake (DM, CP, and NDF) from starter feed (Table 3). There were interactions between diet and time to affect sorting index of particles retained on the $8-\mathrm{mm}(P=0.001)$ and $1.18-\mathrm{mm}(P=0.001)$ sieves of the PSPS (Table 4). During the first period (d 31-40), calves fed CS sorted for particles retained on the 8-mm sieve of the PSPS but did not exhibit sorting behavior during the second period (d 41-50). However, calves on the CS diet began to sort against particles retained on the 8-mm sieve of the PSPS during the third (d 51-60) and fourth (d 61-70) periods. During all studied periods, calves fed RAH sorted for particles retained on the 8-mm sieve of the PSPS. Irrespective of the type of diet fed, all calves sorted for particles retained on the 1.18-mm sieve of the PSPS during all studied periods; however, calves fed CS sorted against particles retained on the 1.18-mm sieve of the PSPS during the third period. Calves fed RAH versus CS sorted more for particles retained on the 8-mm sieve of the PSPS during all studied periods. During the first period, calves fed RBP sorted more for particles retained on the $1.18-\mathrm{mm}$ sieve of the PSPS compared with calves fed CS $(P=0.001)$ or RAH $(P=0.09)$.

\section{Meal Pattern and Chewing Activity}

Before weaning, number of eating bouts per $12 \mathrm{~h}$, bout length, eating rate, and meal size were not affected by diet (Table 5); however, intermeal interval tended to increase $(P=0.06)$ in calves fed RAH compared with calves fed CS. Number of rumination bouts per $12 \mathrm{~h}$, rumination duration, and rumination interval were not affected by diet.

After weaning, meal pattern was not affected by diet. Feeding RAH decreased rumination frequency compared with CS, but it tended to be greater in RAH versus RBP $(P=0.09)$. Rumination duration was greater in calves fed CS and RAH compared with calves fed RBP. Calves fed RBP had longer rumination interval compared with calves fed CS. 
Table 4. Sorting index ${ }^{1}$ as influenced by feeding diets containing $10 \%$ corn silage (CS) and reconstituted alfalfa hay (RAH) or reconstituted beet pulp (RBP) to Holstein calves

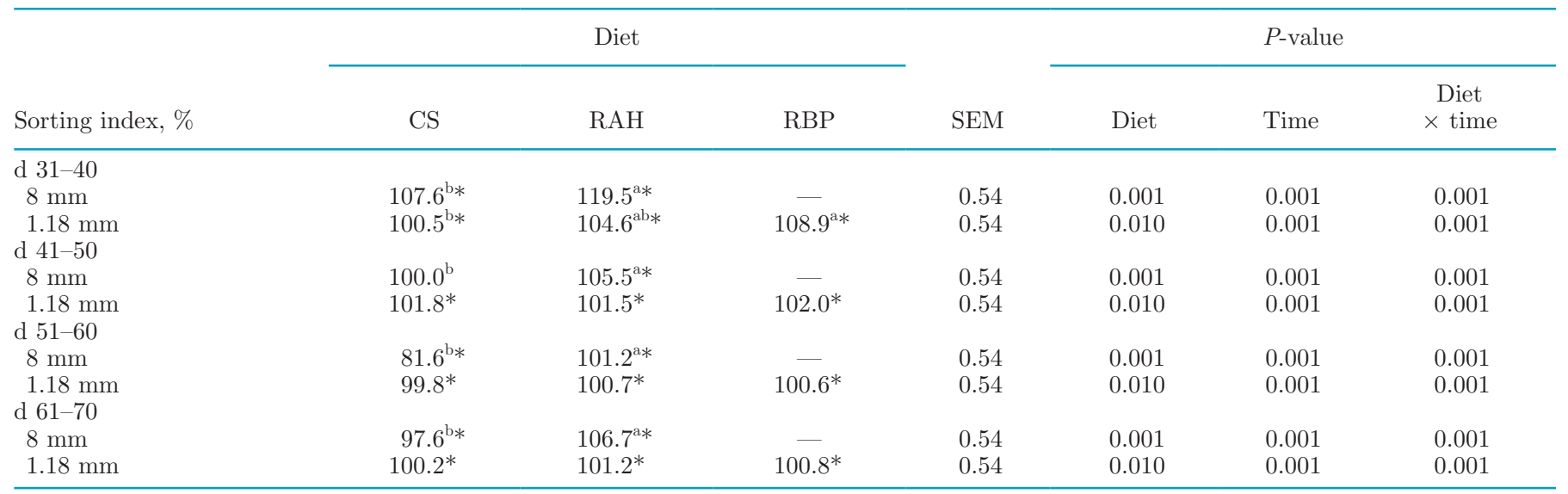

${ }_{\mathrm{a}, \mathrm{b}}$ Means within a row with different superscripts are significantly different $(P \leq 0.05)$.

${ }^{1}$ Sorting $\%=100 \times($ actual particle-size fraction DMI/predicted particle-size fraction DMI). Values equal to $100 \%$ indicate no sorting, $<100 \%$ indicate selective refusals (sorting against), and $>100 \%$ indicate preferential consumption (sorting for). Particle size was determined by the Penn State Particle Separator, which separates the particles in 4 fractions: long ( $>19 \mathrm{~mm})$, medium $(<19$ but $>8 \mathrm{~mm})$, short $(<8$ but $>1.18 \mathrm{~mm})$, and fine $(<1.18 \mathrm{~mm})$. Data are averaged over $10 \mathrm{~d}$ for each 10-d period for 10 calves per treatment.

$* P \leq 0.05$; sorting values differ from $100 \%$.

Before weaning, time spent eating, ruminating, resting, standing, lying, drinking, and NNOB was not affected by diet (Table 6). After weaning, time spent ruminating was greater in calves fed CS compared with calves fed RAH or RBP. Time spent standing tended to increase $(P=0.06)$ in calves fed RBP compared with calves fed CS. Lying time was lower in calves fed CS compared with calves fed RAH or $\operatorname{RBP}(P=0.002)$. Calves fed RBP tended to spend more time engaged in NNOB compared with calves fed RAH $(P=0.07)$.

Table 5. Meal and rumination patterns as influenced by feeding diets containing $10 \%$ corn silage (CS) and reconstituted alfalfa hay $(\mathrm{RAH})$ or reconstituted beet pulp (RBP) to Holstein calves

\begin{tabular}{|c|c|c|c|c|c|}
\hline \multirow[b]{2}{*}{ Item } & \multicolumn{3}{|c|}{ Diet } & \multirow[b]{2}{*}{ SEM } & \multirow{2}{*}{$\begin{array}{c}\text { Diet } \\
P \text {-value }\end{array}$} \\
\hline & CS & $\mathrm{RAH}$ & $\mathrm{RBP}$ & & \\
\hline \multicolumn{6}{|l|}{ Preweaning (d 37-39) } \\
\hline \multicolumn{6}{|l|}{ Meal } \\
\hline Bouts/12 h & 4.9 & 5.0 & 4.7 & 0.47 & 0.84 \\
\hline Length, $\min$ & 8.9 & 9.4 & 9.5 & 0.58 & 0.78 \\
\hline Interval, min & 117.8 & 183.0 & 150.7 & 17.97 & 0.06 \\
\hline Eating rate, $\mathrm{g}$ of starter $\mathrm{DM} / \mathrm{min}$ & 5.8 & 7.0 & 8.8 & 1.08 & 0.16 \\
\hline Meal size, $g$ of starter DM & 52.9 & 65.1 & 79.9 & 11.02 & 0.22 \\
\hline \multicolumn{6}{|l|}{ Rumination } \\
\hline Bouts/12 h & 7.4 & 7.1 & 6.9 & 0.56 & 0.86 \\
\hline Length, min & 15.8 & 17.3 & 15.0 & 0.93 & 0.22 \\
\hline Interval, min & 88.2 & 90.3 & 97.3 & 10.62 & 0.80 \\
\hline \multicolumn{6}{|l|}{ Postweaning (d 67-69) } \\
\hline \multicolumn{6}{|l|}{ Meal } \\
\hline Bouts/12 h & 9.1 & 8.4 & 8.5 & 0.62 & 0.70 \\
\hline Length, min & 9.3 & 10.1 & 8.6 & 0.56 & 0.15 \\
\hline Interval, min & 71.8 & 72.4 & 73.5 & 6.88 & 0.98 \\
\hline Eating rate, $\mathrm{g}$ of starter $\mathrm{DM} / \mathrm{min}$ & 16.6 & 13.8 & 20.3 & 2.88 & 0.28 \\
\hline Meal size, $g$ of starter DM & 139.9 & 137.4 & 164.6 & 19.14 & 0.52 \\
\hline \multicolumn{6}{|l|}{ Rumination } \\
\hline Bouts/12 h & $9.2^{\mathrm{a}}$ & $7.5^{\mathrm{b}}$ & $6.0^{\mathrm{b}}$ & 0.44 & 0.001 \\
\hline Length, min & $18.3^{\mathrm{a}}$ & $16.7^{\mathrm{a}}$ & $12.9^{\mathrm{b}}$ & 0.81 & 0.001 \\
\hline Interval, min & $61.3^{\mathrm{b}}$ & $83.6^{\mathrm{ab}}$ & $101.4^{\mathrm{a}}$ & 8.37 & 0.008 \\
\hline
\end{tabular}

${ }_{\mathrm{a}, \mathrm{b}}$ Means within a row with different superscripts are significantly different $(P \leq 0.05)$. 
Table 6. Chewing behaviors ( $\mathrm{min} / 12 \mathrm{~h}$ ) and times devoted to resting, standing, lying, drinking, and nonnutritive oral behaviors (NNOB) as influenced by feeding diets containing 10\% corn silage (CS) and reconstituted alfalfa hay $(\mathrm{RAH})$ or reconstituted beet pulp (RBP) to Holstein calves

\begin{tabular}{|c|c|c|c|c|c|}
\hline \multirow[b]{2}{*}{ Item } & \multicolumn{3}{|c|}{ Diet } & \multirow[b]{2}{*}{ SEM } & \multirow{2}{*}{$\begin{array}{c}\text { Diet } \\
P \text {-value }\end{array}$} \\
\hline & CS & $\mathrm{RAH}$ & $\mathrm{RBP}$ & & \\
\hline \multicolumn{6}{|c|}{ Preweaning (d 37-39) } \\
\hline Eating time & 44.0 & 46.7 & 42.7 & 5.38 & 0.86 \\
\hline Ruminating time & 116.5 & 120.6 & 103.0 & 12.10 & 0.54 \\
\hline Resting time & 136.0 & 118.4 & 126.0 & 12.33 & 0.62 \\
\hline Standing time & 126.9 & 136.7 & 144.0 & 7.37 & 0.26 \\
\hline Lying time & 233.1 & 251.7 & 254.5 & 16.21 & 0.61 \\
\hline Drinking time & 12.3 & 11.5 & 12.3 & 1.50 & 0.90 \\
\hline NNOB & 51.3 & 34.6 & 37.5 & 6.38 & 0.18 \\
\hline \multicolumn{6}{|c|}{ Postweaning (d 67-69) } \\
\hline Eating time & 83.1 & 83.7 & 72.2 & 7.05 & 0.41 \\
\hline Ruminating time & $166.5^{\mathrm{a}}$ & $122.1^{\mathrm{b}}$ & $77.7^{\mathrm{c}}$ & 7.25 & 0.001 \\
\hline Resting time & 63.3 & 57.7 & 68.7 & 7.37 & 0.57 \\
\hline Standing time & 128.6 & 133.6 & 157.5 & 9.16 & 0.06 \\
\hline Lying time & $236.7^{\mathrm{b}}$ & $290.0^{\mathrm{a}}$ & $290.8^{\mathrm{a}}$ & 10.71 & 0.002 \\
\hline Drinking time & 6.1 & 8.3 & 8.3 & 1.51 & 0.49 \\
\hline NNOB & 35.8 & 24.6 & 44.8 & 6.11 & 0.07 \\
\hline
\end{tabular}

${ }^{\mathrm{a}-\mathrm{c}}$ Means within a row with different superscripts are significantly different $(P \leq 0.05)$.

\section{Health and Blood Total Protein Concentration}

Table 7 presents the logistic models for the occurrence of elevated rectal temperature $\left(\geq 40^{\circ} \mathrm{C}\right)$, general appearance score $\geq 2$, diarrhea (score $\geq 3$ ), pneumonia, and needs for medication before weaning (d 1-49). The occurrence of elevated rectal temperature tended to be greater in $\mathrm{CS}$ versus $\mathrm{RBP}(P=0.08)$. Calves fed $\mathrm{CS}$ and RAH tended to have a lower chance of having pneumonia $(P=0.09)$ but similar chance of administration of medication compared with calves fed RBP.

Table 8 presents the Poisson regression for the frequency and number of days with elevated rectal temperature $\geq 40^{\circ} \mathrm{C}$, general appearance score $\geq 2$, diarrhea score $\geq 3$, and pneumonia and medicated days for both diarrhea and pneumonia. We observed no difference among treatments for the number of days with elevated rectal temperature $\geq 40^{\circ} \mathrm{C}$ or number of days with general appearance score $\geq 2$. Frequency, duration, and medicated days for diarrhea and pneumonia were not affected by diet. Initial blood concentration of total protein $(6.51 \mathrm{~g} / \mathrm{dL}$, on average) was not affected by diet.

\section{DISCUSSION}

By reconstitution, DM content of the RAH and RBP diets reached that of the CS diet $(84.4 \%$, on average; Table 1). At the same levels of moisture $(15.6 \%$, on average) and NDF (16.8\%, on average), DMI was unchanged across treatment groups, which is in line with our hypothesis emphasizing that starter diets with relatively low NDF contents (16-18\%) are recommended to maintain DMI (Beiranvand et al., 2016, 2019; Kargar and Kanani, 2019). When diets containing 32\% alfalfa meal or $34 \%$ BP were fed, Murdock and Wallenius (1980) reported no difference in DMI in dairy calves under 3 mo old. Maktabi et al. (2016) observed no difference in DMI before (d 0-50) and after (d 51-70) weaning when adding $10 \%$ (vs. $0 \%$ ) dry BP to a starter diet of dairy calves. When CS versus dry AH were fed to calves (from early in life) separately from the starter diet, calves on CS consumed a low amount of forage relative to calves on $\mathrm{AH}$, but it was sufficient to foster an increase in starter intake and to maintain total daily DMI between treatments (Castells et al., 2012). Feeding CS (at $15 \%$ of dietary DM) versus dry AH in the starter diets from early in life increased DMI in dairy calves as a result of the lower dustiness or higher palatability of the starter diet with increased dietary moisture due to feeding CS (Mirzaei et al., 2017). Part of the discrepancy between our results and others might be due to the dietary moisture level (Beiranvand et al., 2016, 2019) or eating rate (Kargar and Kanani, 2019). In the present trial, dietary moisture level and eating rate before $(7.2 \mathrm{~g}$ of starter $\mathrm{DM} / \mathrm{min})$ and after $(16.9 \mathrm{~g}$ of starter $\mathrm{DM} / \mathrm{min}$ ) weaning were similar across treatment groups, indicating that calves ate the diets with similar ease. Taken together, our data do not support an effect of forage or nonforage fiber sources at the level used on DMI of dairy calves when dietary moisture or NDF levels were similar across treatment groups.

Overall, calves fed CS sorted against the particles retained on the 8-mm sieve of the PSPS and for the particles retained on the 1.18-mm sieve of the PSPS. Calves fed RAH sorted for the particles retained on the 
Table 7. Logistic model for rectal temperature $\geq 40^{\circ} \mathrm{C}$, general appearance $\geq 2,{ }^{1}$ diarrhea $\geq 3,{ }^{2}$ pneumonia, and medication occurrence during the preweaning ( $\mathrm{d}$ 1-49) period as influenced by feeding diets containing $10 \%$ corn silage (CS) and reconstituted alfalfa hay (RAH) or reconstituted beet pulp (RBP) to Holstein calves

\begin{tabular}{|c|c|c|c|c|c|}
\hline $\begin{array}{l}\text { Variable and } \\
\text { comparison }\end{array}$ & Coefficient & SEM & $\mathrm{OR}^{3}$ & $95 \% \mathrm{CI}$ & $P$-value \\
\hline \multicolumn{6}{|c|}{ Rectal temperature } \\
\hline CS vs. RAH & 0.1692 & 0.47 & 1.18 & $0.47-2.98$ & 0.71 \\
\hline CS vs. RBP & 1.0299 & 0.58 & 2.80 & $0.88-8.88$ & 0.08 \\
\hline RAH vs. RBP & 0.8607 & 0.61 & 2.36 & $0.70-7.93$ & 0.16 \\
\hline \multicolumn{6}{|c|}{ General appearance } \\
\hline CS vs. RAH & 0.3592 & 0.73 & 1.43 & $0.34-6.03$ & 0.62 \\
\hline CS vs. RBP & 0.9214 & 0.83 & 2.51 & $0.48-13.01$ & 0.27 \\
\hline RAH vs. RBP & 0.5622 & 0.91 & 1.75 & $0.29-10.56$ & 0.53 \\
\hline \multicolumn{6}{|c|}{ Diarrhea occurrence } \\
\hline CS vs. RAH & 0.0134 & 0.30 & 1.01 & $0.56-1.82$ & 0.96 \\
\hline CS vs. RBP & -0.1226 & 0.28 & 0.88 & $0.50-1.55$ & 0.66 \\
\hline RAH vs. RBP & -0.1360 & 0.29 & 0.87 & $0.49-1.55$ & 0.64 \\
\hline \multicolumn{6}{|c|}{ Pneumonia occurrence } \\
\hline CS vs. RAH & 0.0000 & 0.81 & 1.00 & $0.20-4.98$ & 1.00 \\
\hline CS vs. RBP & -1.1104 & 0.66 & 0.32 & $0.08-1.22$ & 0.09 \\
\hline RAH vs. RBP & -1.1104 & 0.66 & 0.32 & $0.08-1.22$ & 0.09 \\
\hline \multicolumn{6}{|c|}{ Medication occurrence } \\
\hline \multicolumn{6}{|l|}{ Diarrhea } \\
\hline CS vs. RAH & 0.0287 & 0.30 & 1.02 & $0.56-1.86$ & 0.92 \\
\hline CS vs. RBP & 0.1668 & 0.28 & 1.18 & $0.67-2.08$ & 0.56 \\
\hline RAH vs. RBP & 0.1381 & 0.29 & 1.14 & $0.64-2.04$ & 0.63 \\
\hline \multicolumn{6}{|l|}{ Pneumonia } \\
\hline CS vs. RAH & 0.0000 & 0.81 & 1.00 & $0.20-4.98$ & 1.00 \\
\hline CS vs. RBP & 0.9880 & 0.68 & 2.68 & $0.70-10.17$ & 0.14 \\
\hline RAH vs. RBP & 0.9880 & 0.68 & 2.68 & $0.70-10.17$ & 0.14 \\
\hline
\end{tabular}

${ }^{1} 1=$ normal and alert; $2=$ ears drooped; $3=$ head and ears drooped, dull eyes, slightly lethargic; $4=$ head and ears drooped, dull eyes, lethargic; 5 = severely lethargic (Heinrichs et al., 2003).

${ }^{2} 1=$ normal; $2=$ soft to loose; $3=$ loose to watery; $4=$ watery, mucous, and slightly bloody; $5=$ watery, mucous, and bloody (Heinrichs et al., 2003).

${ }^{3}$ The odds ratio (OR) indicates the probability of having diarrhea or pneumonia, or needing medication for the experimental diets (CS vs. RAH; CS vs. RBP; and RAH vs. RBP). If the $\mathrm{OR}$ is $>1$, a given diet in the comparison is more likely to have diarrhea or pneumonia or to be medicated than the other diet by a factor of the difference above 1 . If the OR is $<1$, a given diet has a lower probability of occurrence than the other diet.

Table 8. Initial (d 3) blood total protein $(\mathrm{g} / \mathrm{dL})$ and Poisson regression for days with rectal temperature $\geq 40^{\circ} \mathrm{C}$ and general appearance $\geq 2,{ }^{1}$ and frequency and duration of diarrhea $\geq 3,{ }^{2}$ pneumonia, and days medicated during the preweaning ( $1-49)$ period as influenced by feeding diets containing $10 \%$ corn silage (CS) and reconstituted alfalfa hay $(\mathrm{RAH})$ or reconstituted beet pulp (RBP) to Holstein calves

\begin{tabular}{|c|c|c|c|c|c|}
\hline \multirow[b]{2}{*}{ Item } & \multicolumn{3}{|c|}{ Diet } & \multirow[b]{2}{*}{ SEM } & \multirow{2}{*}{$\begin{array}{c}\text { Diet } \\
P \text {-value }\end{array}$} \\
\hline & CS & $\mathrm{RAH}$ & $\mathrm{RBP}$ & & \\
\hline Initial blood total protein & 6.08 & 6.83 & 6.61 & 0.301 & 0.26 \\
\hline Days with rectal temperature $\geq 40^{\circ} \mathrm{C}$ & 1.10 & 0.88 & 0.40 & 0.482 & 0.40 \\
\hline Days with general appearance $\geq 2$ & 0.50 & 0.33 & 0.20 & 0.120 & 1.00 \\
\hline \multicolumn{6}{|l|}{ Diarrhea } \\
\hline Frequency, times diagnosed & 0.90 & 1.00 & 0.70 & 0.353 & 0.81 \\
\hline Duration, d & 2.40 & 2.44 & 2.70 & 0.211 & 0.97 \\
\hline Medicated, d & 3.00 & 4.00 & 2.90 & 0.181 & 0.38 \\
\hline \multicolumn{6}{|l|}{ Pneumonia } \\
\hline Frequency, times diagnosed & 0.10 & 0.11 & 0.30 & 0.091 & 0.51 \\
\hline Duration, d & 0.30 & 0.33 & 0.90 & 0.290 & 0.13 \\
\hline Medicated, d & 0.30 & 0.33 & 0.80 & 0.254 & 0.22 \\
\hline
\end{tabular}

${ }^{1} 1=$ normal and alert; $2=$ ears drooped; $3=$ head and ears drooped, dull eyes, slightly lethargic; $4=$ head and ears drooped, dull eyes, lethargic; $5=$ severely lethargic (Heinrichs et al., 2003).

${ }^{2} 1=$ normal; $2=$ soft to loose; $3=$ loose to watery; $4=$ watery, mucous, and slightly bloody; $5=$ watery, mucous, and bloody (Heinrichs et al., 2003). 
8- and 1.18-mm sieves of the PSPS, and calves on the RBP diet sorted only for the particles retained on the 1.18-mm sieve of the PSPS. Kargar and Kanani (2019) observed that dairy calves fed TMR diets containing $10 \%$ (dietary DM) RAH versus dry AH from early in life sorted less for the particles retained on the 8-mm sieve of the PSPS, with no difference on the particles retained on the 1.18-mm sieve of the PSPS. MillerCushon et al. (2013) observed that calves fed a TMR diet containing $30 \%$ chopped ryegrass hay sorted against concentrate before weaning (wk 6 of life) but sorted for concentrate after weaning (wk 8 of life), indicating an increased reliance on starter diet for energy following weaning. Despite limited previous research on providing silage-based TMR to calves, Overvest et al. (2016) observed that early postweaned dairy calves fed a TMR $\operatorname{diet}(51.5 \% \mathrm{DM})$ containing $37 \%$ (dietary DM) CS did not show any sorting activity, whereas calves fed a dry TMR diet containing 15\% (dietary DM) chopped grass hay sorted against longer particles. Costa et al. (2016) offered access to a TMR diet [containing a mixture of CS $(26.1 \%)$, grass silage (14.8\%), and AH (10.0\%)] in young calves from early in life and observed that, at 10 d after weaning, calves sorted for the long forage particles in the TMR and against the small particles. However, this direction of sorting changed on the day after removal of the supplemental calf starter concentrate, with calves sorting in favor of the fine particles of the TMR. Inconsistencies between the results of the present study and the above-mentioned studies are difficult to elucidate, although approaches to measuring feed sorting (using complete nutrient analysis of provided and refused feed as an indicator of sorting between forage and concentrate components or using particlesize analysis, which may not have fully distinguished between ration ingredients, such as chopped forage and concentrate) did vary among studies. Taken together, results from the present trial and above-mentioned studies suggest that the sorting behavior of young calves may depend on the availability of other nutrient sources. To our knowledge, no similar published data on the effect of RBP on the sorting behavior of dairy calves are available for comparison.

Although sorting behavior is generally attributed to TMR-fed heifers and cattle, calves are also capable of actively sorting a TMR diet from early in life, which is determined by nutritional demands, rumen characteristics, or calves' motivation to show chewing activity (Costa et al., 2016). From other view, sorting activity can help animals achieve the required levels of nutrient intake (Kargar and Kanani, 2019). For example, dairy heifers fed TMR diets diluted with straw that limited DMI sorted against the long particles and for the shorter particles so that their actual nutrient in- takes matched those required for their targeted level of growth (Greter et al., 2008). Because calves are thought to learn through physiological postingestive feedback mechanisms (Provenza, 1995), our results indicate that calves fed TMR diets from early in life learn to balance nutrient intake in ways that support growth and alleviate the effects of lower rumen $\mathrm{pH}$ (Kargar and Kanani, 2019). This was substantiated by similar final BW $(87.8,90.5$, and $92.1 \mathrm{~kg}$ for CS, RAH, and RBP, respectively; $\mathrm{SEM}=2.68 ; P=0.70$; unpublished data) and rumen fluid $\mathrm{pH}[5.54,5.56$, and 5.67 for $\mathrm{CS}, \mathrm{RAH}$, and $\mathrm{RBP}$, respectively; SEM $=0.16 ; P=0.82$; S. Kargar, M. Kanani, M. Albenzio (Department of the Sciences of Agriculture, Food and Environment, University of Foggia, Foggia, Italy), and M. Caroprese (Department of the Sciences of Agriculture, Food and Environment, University of Foggia), unpublished data] across treatment groups in a companion study. Despite this, calves fed RAH versus CS may be sorting for longer particles due to consuming a high-grain and high-starch diet and thereby having a greater need to buffer rumen as peNDF; thereby, geometric mean particle size was shifted by replacing CS with RAH (Table 2).

Dry matter intake is a function of both meal size and intermeal interval, determined by satiety and hunger, respectively (Kargar et al., 2018; Kargar and Kanani, 2019). The lack of diet effect on DMI (pre- and postweaning) may be attributed to no significant changes in meal size or intermeal interval; however, a tendency for longer intermeal interval in calves fed RAH versus CS before weaning was compensated with numerically higher meal length $(6 \%)$ or eating rate $(21 \%)$; therefore, no diet effect was detected on time devoted to eating across treatment groups. A higher rumination frequency and rumination duration or lower interval between bouts in calves fed CS resulted in an increase in time spent ruminating compared with calves fed RAH (44 min) or RBP (89 min). The increase in time spent ruminating in CS-fed calves may be in part due to greater selective consumption of NDF from particles retained on the $8-\mathrm{mm}$ sieve of the PSPS (19 vs. 10 $\mathrm{g} / \mathrm{d}$ for CS vs. RAH, respectively; $\mathrm{SEM}=1.14 ; P=$ 0.001; data not shown); however, increased consumption of NDF from particles retained on the $1.18-\mathrm{mm}$ sieve of the PSPS in calves fed RBP (90 vs. $125 \mathrm{~g} / \mathrm{d}$ for CS vs. RBP, respectively; $\mathrm{SEM}=9.27 ; P=0.002$; data not shown) was unable to attenuate the severity of reduction in time devoted to rumination because of the lower potential of shorter particles in encouraging rumination (Table 4; Kargar et al., 2013, 2014). The reason(s) for reductions in times spent to standing and lying in calves fed CS versus RBP and a decrease in time spent engaged in NNOB in calves fed RAH versus RBP are unknown. Castells et al. (2012) reported no 
differences in times devoted to standing, lying, and NNOB when CS and dry AH were fed separately from the starter diet to young calves. Mirzaei et al. (2017) reported no differences in times devoted to standing and lying but lower time devoted to NNOB in calves fed TMR containing $15 \%$ dry AH versus CS from early in life; however, rumination time was higher for CS-fed calves. To our knowledge, no similar published data on the effect of replacing CS with RAH or RBP at $10 \%$ of dietary DM on the feeding behavior of dairy calves are available for comparison.

Before weaning, calves fed RBP tended to have a lower probability of rectal temperature $\geq 40^{\circ} \mathrm{C}$ compared with calves fed CS; however, number of days with rectal temperature $\geq 40^{\circ} \mathrm{C}$ was similar between both treatment groups. Calves fed CS and RAH compared with calves fed RBP tended to have a lower probability of having pneumonia with similar chance to be treated before weaning. However, there was no difference across treatment groups for frequency, duration, and medication days of diseases, indicating that calves, in general, were healthy. All calves in the present study were fed approximately $14 \%$ colostrum of their BW within 8 to $10 \mathrm{~h}$ of birth. This level of colostrum feeding was described to be sufficient to achieve a satisfactory level of serum $\operatorname{IgG}[10 \mathrm{mg} / \mathrm{mL}$, which is substantiated with higher initial blood total protein $(6.51 \mathrm{~g} / \mathrm{dL})$ in the present study] in calves to combat infectious diseases during the milk-feeding period (Woodward, 1998; Nonnecke et al., 2003). Furthermore, calves received a more balanced nutrient intake by feeding TMR, which is essential for health (Conneely et al., 2014), in addition to good sanitary and housing management conditions. All mentioned practices are effective in optimizing the calf's health and well-being at the early stage of calf life.

\section{CONCLUSIONS}

Replacing CS with RAH or RBP did not affect DMI before and after weaning, and thereby no significant changes in meal size or intermeal interval were detected. Regardless of the type of dietary treatment fed, calves showed feed sorting to the extent that balanced intake of nutrients and met their nutritional needs. Finally, all diets performed equally in terms of affecting feed intake, meal pattern, and general health; therefore, CS, $\mathrm{RAH}$, or RBP can be used interchangeably based on availability and feed relative costs.

\section{ACKNOWLEDGMENTS}

The authors thank Shiraz University (Shiraz, Iran) for providing suitable experimental conditions. The authors also express their kind appreciation to the farm staff at Foudeh-Sepahan Agriculture and Animal Husbandry (Isfahan, Iran) for diligent animal care. We also thank J. H. C. Costa (University of Kentucky, Lexington) for his helpful review of the manuscript.

\section{REFERENCES}

AOAC International. 2002. Official Methods of Analysis. 17th ed. AOAC International, Arlington, VA.

ASAE (American Society of Agricultural Engineers). 1995. Method of determining and expressing fineness of feed material by sieving. Method S424.1. Page 461 in ASAE Standards 1995. ASAE, St. Joseph, MI.

Beiranvand, H., M. Khani, F. Ahmadi, H. Omidi-Mirzaei, M. Ariana, and A. R. Bayat. 2019. Does adding water to a dry starter diet improve calf performance during winter? Animal 13:959-967. https:/ /doi.org/10.1017/S1751731118002367.

Beiranvand, H., M. Khani, S. Omidian, M. Ariana, R. Rezvani, and M. H. Ghaffari. 2016. Does adding water to dry calf starter improve performance during summer? J. Dairy Sci. 99:1903-1911.

Borland, K., and E. M. Kesler. 1979. Complete rations for Holstein calves 8 to 18 weeks of age. J. Dairy Sci. 62:304-309.

Castells, L., A. Bach, G. Araujo, C. Montoro, and M. Terré. 2012. Effect of different forage sources on performance and feeding behavior of Holstein calves. J. Dairy Sci. 95:286-293.

Conneely, M., D. P. Berry, J. P. Murphy, I. Lorenz, M. L. Doherty, and E. Kennedy. 2014. Short communication: Effects of milk feeding volume and frequency on body weight and health of dairy heifer calves. Livest. Sci. 161:90-94.

Costa, J. H. C., N. A. Adderley, D. M. Weary, and M. A. G. vonKeyserlingk. 2016. Short communication: Effect of diet changes on sorting behavior of weaned dairy calves. J. Dairy Sci. 99:56355639.

DeVries, T. J., M. A. G. von Keyserlingk, and K. A. Beauchemin. 2005. Frequency of feed delivery affects the behavior of lactating dairy cows. J. Dairy Sci. 88:3553-3562.

Greter, A. M., and T. J. DeVries. 2011. Effect of feeding amount on the feeding and sorting behaviour of lactating dairy cattle. Can. J. Anim. Sci. 91:47-54.

Greter, A. M., T. J. DeVries, and M. A. G. von Keyserlingk. 2008. Nutrient intake and feeding behavior of growing dairy heifers: Effects of dietary dilution. J. Dairy Sci. 91:2786-2795.

Greter, A. M., K. E. Leslie, G. J. Mason, B. W. McBride, and T. J. DeVries. 2010. Effect of feed delivery method on the behavior and growth of dairy heifers. J. Dairy Sci. 93:1668-1676.

Heinrichs, A. J., C. M. Jones, L. R. VanRoekel, and M. A. Fowler. 2003. Calf Track: A system of dairy calf workforce management, training, and evaluation and health evaluation. J. Dairy Sci. 86(Suppl. 1):115. (Abstr.)

Imani, M., M. Mirzaei, B. Baghbanzadeh-Nobari, and M. H. Ghaffari. 2017. Effects of forage provision to dairy calves on growth performance and rumen fermentation: A meta-analysis and metaregression. J. Dairy Sci. 100:1136-1150.

Iranian Council of Animal Care. 1995. Guide to the Care and Use of Experimental Animals. Vol. 1. Isfahan University of Technology, Isfahan, Iran.

Kargar, S., G. R. Ghorbani, M. Khorvash, E. Kamalian, and D. J. Schingoethe. 2013. Dietary grain source and oil supplement: Feeding behavior and lactational performance of Holstein cows. Livest. Sci. 157:162-172.

Kargar, S., G. R. Ghorbani, M. Khorvash, A. Sadeghi-Sefidmazgi, and D. J. Schingoethe. 2014. Reciprocal combinations of barley and corn grains in oil-supplemented diets: Feeding behavior and milk yield of lactating cows. J. Dairy Sci. 97:7001-7011.

Kargar, S., and M. Kanani. 2019. Reconstituted versus dry alfalfa hay in starter feed diets of Holstein dairy calves: Effects on feed intake, feeding and chewing behavior, feed preference, and health 
criteria. J. Dairy Sci. 102:4061-4071. https://doi.org/10.3168/jds 2018-15189.

Kargar, S., F. Mousavi, S. Karimi-Dehkordi, and M. H. Ghaffari. 2018. Growth performance, feeding behavior, health status, and blood metabolites of environmentally heat-loaded Holstein dairy calves fed diets supplemented with chromium. J. Dairy Sci. 101:98769887.

Kononoff, P. J., A. J. Heinrichs, and D. R. Buckmaster. 2003. Modification of the Penn State forage and total mixed ration particle separator and the effects of moisture content on its measurements. J. Dairy Sci. 86:1858-1863.

Leonardi, C., and L. E. Armentano. 2003. Effect of quantity, quality, and length of alfalfa hay on selective consumption by dairy cows. J. Dairy Sci. 86:557-564.

Leonardi, C., F. Giannico, and L. E. Armentano. 2005. Effect of water addition on selective consumption (sorting) of dry diets by dairy cattle. J. Dairy Sci. 88:1043-1049.

Maktabi, H., E. Ghasemi, and M. Khorvash. 2016. Effects of substituting grain with forage or nonforage fiber source on growth performance, rumen fermentation, and chewing activity of dairy calves. Anim. Feed Sci. Technol. 221:70-78.

Miller-Cushon, E. K., R. Bergeron, K. E. Leslie, G. J. Mason, and T. J. DeVries. 2013. Effect of early exposure to different feed presentations on feed sorting of dairy calves. J. Dairy Sci. 96:4624-4633.

Mirzaei, M., M. Khorvash, G. R. Ghorbani, M. Kazemi-Bonchenari, and M. H. Ghaffari. 2017. Growth performance, feeding behavior, and selected blood metabolites of Holstein dairy calves fed re- stricted amounts of milk: No interactions between sources of finely ground grain and forage provision. J. Dairy Sci. 100:1086-1094.

Mirzaei, M., M. Khorvash, G. R. Ghorbani, M. Kazemi-Bonchenari, A. Riasi, A. Soltani, B. Moshiri, and M. H. Ghaffari. 2016. Interactions between the physical form of starter (mashed versus textured) and corn silage provision on performance, rumen fermentation, and structural growth of Holstein calves. J. Anim. Sci. 94:678-686.

Murdock, F. R., and R. W. Wallenius. 1980. Fiber sources for complete calf starter rations. J. Dairy Sci. 63:1869-1873.

Nonnecke, B. J., M. R. Foote, J. M. Smith, B. A. Pesch, and M. E. Van Amburgh. 2003. Composition and functional capacity of blood mononuclear leukocyte populations from neonatal calves on standard and intensified milk replacer diets. J. Dairy Sci. 86:35923604 .

NRC. 2001. Nutrient Requirements of Dairy Cattle. 7th rev. ed. Natl. Acad. Sci., Washington, DC.

Overvest, M. A., R. Bergeron, D. B. Haley, and T. J. DeVries. 2016. Effect of feed type and method of presentation on feeding behavior, intake, and growth of dairy calves fed a high level of milk. J. Dairy Sci. 99:317-327.

Provenza, F. D. 1995. Postingestive feedback as an elementary determinant of food preference and intake in ruminants. J. Range Manage. 48:2-17.

Woodward, B. 1998. Protein, calories, and immune defenses. Nutr. Rev. 56:S84-S92. 